\title{
PRACTICAL \\ MOTHER AND CHILD \\ HEALTH IN \\ DEVELOPING COUNTRIES
}

G. J. EBRAHIM

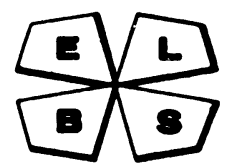

ENGLISH LANGUAGE BOOK SOCIETY

and

MACMILLAN EDUCATION 
(c) G.J. Ebrahim 1978

All rights reserved. No part of this publication may be reproduced or transmitted, in any form or by any means, without permission.

First published 1978 by

THE MACMILLAN PRESS LTD

London and Basingstoke

Associated companies in Delhi Dublin

Hong Kong Johannesbury Lagos Melbourne

New York Singapore and Tokyo

Reprinted 1979

ELBS edition first published 1980

ELBS edition reprinted 1982

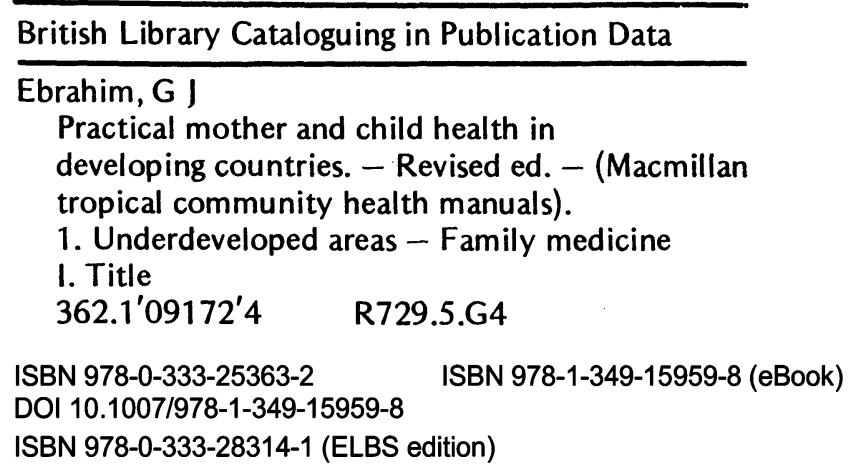

This book is sold subject to the standard conditions of the Net Book Agreement.

The paperback edition of this book is sold subject to the condition that it shall not, by way of trade or otherwise, be lent, resold, hired out, or otherwise circulated without the publisher's prior consent in any form of binding or cover other than that in which it is published and without a similar condition including this condition being imposed on the subsequent purchaser. 


\title{
Contents
}

\author{
Preface
}

1. Maternal and Child Health: Introduction 1

2. Antenatal Care 7

3. Nutrition of the Pregnant Woman 14

4. The Delivery of the Baby 17

5. Care of the Newborn 20

6. Resuscitation of the Newborn 24

7. The Low Birth Weight Baby 28

8. Breast-Feeding 34

9. Growth and Development 39

10. Weaning 42

11. The Under-fives Clinic 46

12. Immunisation in Childhood 56

13. Feeding the Infant and Young Child

(by Anne and Dr. H. J. L. Burgess) 62

14. Nutrition Rehabilitation 66

15. The Pre-school Child 72

16. Day Care Centres 77

17. Problems of Urbanisation

18. Health Education 82

19. Home-visiting 84

20. The 'At Risk' Concept 87

21. Community Participation in Health Programmes. 91

22. School Health Service 97

23. Assessing Health Programmes 101

24. Prevention of Communicable Diseases in Children 106

25. Clean Water 109

26. Handicapping and Chronic IIInesses 115

27. Child Spacing 124

$\begin{array}{ll}\text { Index } & 129\end{array}$ 
Some other ELBS low-priced editions

\begin{tabular}{|c|c|c|c|}
\hline $\begin{array}{l}\text { Alleyne, Hay } \\
\text { Picou, Stanfield } \\
\text { and Whitehead }\end{array}$ & PROTEIN-ENERGY MALNUTRITION & & Iward Arnold \\
\hline $\begin{array}{l}\text { Browne, McClure } \\
\text { and Dixon }\end{array}$ & BROWNE'S ANTENATAL CARE & \multicolumn{2}{|c|}{ Churchill Livingstone } \\
\hline $\begin{array}{l}\text { yrne and } \\
\text { ennett }\end{array}$ & $\begin{array}{l}\text { COMMUNITY NURSING IN } \\
\text { DEVELOPING COUNTRIES }\end{array}$ & \multicolumn{2}{|c|}{$\begin{array}{r}\text { Oxford University } \\
\text { Press }\end{array}$} \\
\hline $\begin{array}{l}\text { heesbrough } \\
\text { nd McArthur }\end{array}$ & $\begin{array}{l}\text { A LABORATORY MANUAL FOR } \\
\text { RURAL TROPICAL HOSPITALS }\end{array}$ & \multicolumn{2}{|c|}{ Churchill Livingstone } \\
\hline $\begin{array}{l}\text { avidson, } \\
\text { assmore, Brock } \\
\text { nd Truswell }\end{array}$ & $\begin{array}{l}\text { HUMAN NUTRITION AND } \\
\text { DIETETICS }\end{array}$ & \multicolumn{2}{|c|}{ Churchill Livingstone } \\
\hline brahim & $\begin{array}{l}\text { BREAST FEEDING: THE BIOLOGICA } \\
\text { OPTION }\end{array}$ & \\
\hline brahi & $\begin{array}{l}\text { CARE OF THE NEWBORN IN } \\
\text { DEVELOPING COUNTRIES }\end{array}$ & \multicolumn{2}{|r|}{ Macmillan } \\
\hline brahim & $\begin{array}{l}\text { A HANDBOOK OF TROPICAL } \\
\text { PAEDIATRICS }\end{array}$ & & Macmillan \\
\hline Ebrahim & $\begin{array}{l}\text { PRACTICAL MOTHER AND CHILD } \\
\text { IN DEVELOPING COUNTRIES }\end{array}$ & ALTH & Macmillan \\
\hline Jelliffe & CHILD HEALTH IN THE TROPICS & \multicolumn{2}{|c|}{ Edward Arnold } \\
\hline $\begin{array}{l}\text { Jelliffe and } \\
\text { Jelliffe }\end{array}$ & $\begin{array}{l}\text { HUMAN MILK IN THE MODERN } \\
\text { WORLD }\end{array}$ & \multicolumn{2}{|c|}{$\begin{array}{r}\text { Oxford University } \\
\text { Press }\end{array}$} \\
\hline $\begin{array}{l}\text { Jelliffe and } \\
\text { Stanfield }\end{array}$ & $\begin{array}{l}\text { DISEASES OF CHILDREN IN THE } \\
\text { SUBTROPICS AND TROPICS }\end{array}$ & \multicolumn{2}{|c|}{ Edward Arnolo } \\
\hline Jolly & DISEASES OF CHILDREN & \multicolumn{2}{|c|}{ Blackwell Scientific } \\
\hline King & $\begin{array}{l}\text { A MEDICAL LABORATORY FOR } \\
\text { DEVELOPING COUNTRIES }\end{array}$ & \multicolumn{2}{|c|}{$\begin{array}{r}\text { Oxford University } \\
\text { Press }\end{array}$} \\
\hline $\begin{array}{l}\text { King, King, } \\
\text { Morley, Burgess } \\
\text { and Burgess }\end{array}$ & $\begin{array}{l}\text { NUTRITION FOR DEVELOPING } \\
\text { COUNTRIES }\end{array}$ & \multicolumn{2}{|c|}{$\begin{array}{r}\text { Oxford University } \\
\text { Press }\end{array}$} \\
\hline $\begin{array}{l}\text { Lawson and } \\
\text { Stewart }\end{array}$ & $\begin{array}{l}\text { OBSTETRICS AND GYNAECOLOGY } \\
\text { THE TROPICS AND DEVELOPING CC }\end{array}$ & \multicolumn{2}{|c|}{$\begin{array}{l}\text { E Edward Arnold } \\
\text { UNTRIES }\end{array}$} \\
\hline Sweet & MAYES' MIDWIFERY & \multicolumn{2}{|c|}{ Bailliere Tindall } \\
\hline Morley & $\begin{array}{l}\text { PAEDIATRIC PRIORITIES IN THE } \\
\text { DEVELOPING WORLD }\end{array}$ & \multicolumn{2}{|r|}{ Butterworth } \\
\hline Myles & TEXTBOOK FOR MIDWIVES & \multicolumn{2}{|c|}{ Churchill Livingstone } \\
\hline $\begin{array}{l}\text { Nilliams and } \\
\text { elliffe }\end{array}$ & MOTHER AND CHILD HEALTH & \multicolumn{2}{|c|}{$\begin{array}{r}\text { Oxford University } \\
\text { Press }\end{array}$} \\
\hline
\end{tabular}




\section{Preface}

Two thirds of humanity lives in the developing world, where 80 per cent or more of the population lives in rural areas. Young people under the age of fifteen and women in child bearing age comprise more than half of the population of an average developing country. It is surprising that no special services have been evolved for these groups. True there are obstetric, paediatric, nutrition and preventive services. But these are compartmentalised and rarely, if ever, become integrated enough to be called a service for promoting the health of mothers and children within the family and community environment.

Mother and Child Health (MCH) is not a new speciality. It is a method of delivering health care to the most vulnerable groups in society. In many countries existing health services are oriented towards providing a high standard of care for the urban populations. More than three-quarters of the recurrent health budget of the average developing country is spent on curative care which is, of necessity, based on hospitals in large towns and cities. A large proportion of the health manpower is also engaged in these hospitals. Even though a variety of health programmes are expected to reach out of the hospitals to the wider community, in effect this is hardly so. Several evaluations of health care in different countries have revealed that not more than 20 per cent of the rural population is adequately covered with basic health services.

Teaching programmes generally reflect the administrative arrangements in the health service. In the medical and nursing curriculum time is allotted for the teaching of obstetrics, paediatrics, nutrition and preventive and social medicine. It is taken for granted that synthesis will take place in the mind of the student and an understanding of mother and child health will eventually occur. There is little evidence to support such a belief, and a thorough revision of training curricula is necessary to create a place for proper training in mother and child health.

In the rural areas, in shanty towns and even in many inner city areas health care for mothers and children is usually the responsibility of auxiliaries. It is all the more necessary that they receive adequate 
training in the subject. A sound knowledge of mother and child health is also important for the physician and the paediatrician because they are called upon to co-ordinate all MCH activities in their district or area.

This book arose out of the author's experience in Tanzania. As the only paediatrician in the country for ten years after independence he was engaged in developing child health services and in setting up relevant training programmes. Since then as tutor to the WHO/UNICEF sponsored Course for Senior Teachers of Child Health for eight years there have been opportunities for studying the health problems in the rural areas of several countries. As a result of these experiences extensive revision and addition of new material has been made in the present edition of the book.

Practical Mother and Child Health in Developing Countries is one of a set of four manuals which comprise the Health Centre Set, and is intended for the community health nurse at the rural health centre. Each of the other manuals in the set is intended for a specific member of the health team. It is hoped that these texts wil! contribute to improving the standards of care and the teaching of mother and child health in the developing world. 